\begin{tabular}{|c|c|c|c|c|}
\hline $\begin{array}{c}\text { Prosiding Penelitian \& } \\
\begin{array}{c}\text { Pengabdian Kepada } \\
\text { Masyarakat }\end{array}\end{array}$ & $\begin{array}{c}\text { e ISSN : 2581-1126 } \\
\text { p ISSN : 2442-448X }\end{array}$ & Vol 7, No: 1 & Hal: $179-186$ & April 2020 \\
\hline
\end{tabular}

\title{
PENERAPAN KONSEP EKOWISATA DI KECAMATAN CIHURIP KABUPATEN GARUT DALAM RANGKA PERLINDUNGAN DAN PENGELOLAAN LINGKUNGAN
}

\author{
Yulinda Adharani ${ }^{1}$, Yusuf Saepul Zamil ${ }^{2}$, Nadia Astriani ${ }^{3}$, Siti Sarah Afifah ${ }^{4}$ \\ 1,2,3,4 Universitas Padjadjaran \\ 1yulinda.adharani@gmail.com, ${ }^{2} y u s u f . z a m i l @ g m a i l . c o m,{ }^{3}$ Nadia.astriani@unpad.ac.id, ${ }^{4}$ sitisarahafifah@g \\ mail.com
}

\begin{abstract}
ABSTRAK
Berbagai wilayah di Indonesia seringkali menjadi objek wisata yang dapat meningkatkan kesejahteraan masyarakat sekitarnya. Potensi tersebut dapat dimanfaatkan dengan mengembangkan dan melestarikan sumber daya alam melalui ekowisata, yang merupakan suatu bentuk wisata yang erat dengan prinsip konservasi, menggunakan strategi konservasi untuk mempertahankan keutuhan dan keaslian ekosistem di wilayah yang masih alami, sekaligus meningkatkan kesejahteraan ekonomi masyarakat di wilayah tersebut. Salah satunya objek wisata yang terdapat di Kecamatan Cihurip Kabupaten Garut. Artikel ini akan membahas bagaimana ekowisata dapat mendukung perlindungan dan pengelolaan lingkungan, dan bagaimana konsep ekowisata diterapkan pada objek wisata yang terdapat di Kecamatan Cihurip Kabupaten Garut.

Penelitian ini dilakukan dengan menggunakan metode pendekatan juridis normatif dalam arti menggunakan data kepustakaan/sekunder sebagai bahan utama penelitian. Dalam hal ini digunakan metode penelitian yang bersifat deskriptif analitis dengan pendekatan sistemik.

Pengembangan ekowisata harus memperhatikan prinsip ekowisata dan kesinambungan antara lingkungan, masyarakat dan pergerakan perekonomian yang terjadi sebelum dan selama ekowisata dijalankan. Selain itu, dalam penyelenggaraan dan pengelolaan kawasan ekowisata, harus memperhatikan unsur pendidikan, perlindungan, keterlibatan masyarakat lokal, pengawasan, dan konservasi. Keterlibatan penduduk lokal harus dimaksimalkan dengan tujuan meningkatkan ekonomi masyarakat setempat.
\end{abstract}

\begin{abstract}
Various regions in Indonesia often become tourist objects that can improve the welfare of the surrounding community. This potential can be utilized by developing and conserving natural resources through ecotourism, which is a form of tourism that is closely related to the principle of conservation, using conservation strategies to maintain the integrity and authenticity of ecosystems in unspoiled areas, while increasing the economic well-being of people in the region. One of them is a tourist attraction in Cihurip District, Garut Regency. This article will discuss how ecotourism can support the protection and management of the environment, and how the concept of ecotourism is applied to the attractions found in the District of Cihurip, Garut Regency.

This research was conducted by using a normative juridical approach in the sense of using library / secondary data as the main material of research. In this case, the method used is descriptive analytical research with a systemic approach.

Ecotourism development must pay attention to the principles of ecotourism and sustainability between the environment, the community and economic movements that occur before and during ecotourism. In addition, in the implementation and management of ecotourism areas, it must pay attention to the elements of education, protection, local community involvement, supervision, and conservation. The involvement of local residents must be maximized with the aim of improving the economy of the local community.
\end{abstract}

Keywords: Ecotourism; Protection; Management; Environment. 


\begin{tabular}{|c|c|c|c|c|}
\hline $\begin{array}{c}\text { Prosiding Penelitian \& } \\
\begin{array}{c}\text { Pengabdian Kepada } \\
\text { Masyarakat }\end{array}\end{array}$ & $\begin{array}{c}\text { e ISSN : 2581-1126 } \\
\text { p ISSN : 2442-448X }\end{array}$ & Vol 7, No: 1 & Hal: $179-186$ & April 2020 \\
\hline
\end{tabular}

\section{PENDAHULUAN}

\section{Latar Belakang}

Setiap daerah di Indonesia memiliki potensi mengembangakan daerahnya untuk menyejahterakan masyarakat di daerah tersebut. Salah satu potensi tersebut adalah pengembangan dan pelestarian sumber daya alam melalui ekowisata, yang merupakan suatu bentuk wisata yang erat dengan prinsip konservasi, menggunakan strategi konservasi untuk mempertahankan keutuhan dan keaslian ekosistem di wilayah yang masih alami, sekaligus meningkatkan kesejahteraan ekonomi masyarakat di wilayah tersebut.

Salah satu potensi sektor unggulan daerah yang belum dikembangkan secara optimal, maka perlu pengembangan ekowisata di daerah tersebut secara optimal dengan strategi perencanaan, pemanfaatan, pengendalian, penguatan kelembagaan, dan pemberdayaan masyarakat dengan memperhatikan kaidah-kaidah sosial, ekonomi, ekologi, dan melibatkan pemangku kepentingan.

Konsep ekowisata di dunia pertama kali diperkenalkan oleh pakar ekowisata yang telah lama menggeluti perjalanan alam, yakni Hector Ceballos dan Lascurain pada tahun 1987. Kemudian, The Ecotourism Society pada 1993 menyempurnakan konsep ekowisata dengan mendefinisikan sebagai suatu perjalanan bertanggung jawab pada lingkungan alami yang mendukung konservasi dan meningkatkan kesejahteraan penduduk setempat.

Pemahaman terhadap ecotourism berjalan mengikuti kemajuan pembangunan ekonomi, ilmu pengetahuan dan teknologi, serta peningkatan kesadaran global terhadap aspek-aspek lingkungan. Pemahaman tersebut mengungkap makna penting perihal nilai-nilai budaya lokal dan hubungannya dengan pengelolaan lingkungan. Nilai-nilai lokal secara ekologi telah terbukti sebagai komponen penting upaya konservasi keanekaragaman hayati. Kerangka berpikir tersebut menjadi landasan tersusunnya definisi atau batasan ecotourism. Menurut UndangUndang Nomor 10 Tahun 2009 tentang Kepariwisataan, yang dimaksud dengan pariwisata ialah berbagai macam kegiatan wisata dan didukung oleh berbagai fasilitas serta layanan yang disediakan masyarakat, pengusaha, Pemerintah, dan Pemerintah Daerah.
Kabupaten Garut merupakan salah satu daerah yang memiliki keindahan alam menawan salah satunya berada di Kecamatan Cihurip. Tempat wisata tersebut adalah Curug Nyogong, Curug Cibadak, Situ Ranca Hideung dan Leuwi Tonjong. Namun di balik keindahan alam tersebut terdapat dampak berupa kerusakan lingkungan, terpengaruhnya budaya lokal secara tidak terkontrol, berkurangnya peran masyarakat setempat dan persaingan bisnis yang mulai mengancam lingkungan, budaya dan ekonomi masyarakat setempat. Pada mulanya ekowisata dijalankan dengan cara membawa wisatawan ke objek wisata alam yang eksotis dengan cara ramah lingkungan namun kurangnya perhatian terhadap lingkungan akan menurunkan keindahan tempat wisata itu sendiri.

Merujuk pada definisi ekowisata yang dirumuskan pada Rencana Strategi Pengembangan Ekowisata Nasional yang menyatakan bahwa ekowisata adalah suatu konsep pengembangan dan penyelenggaraan kegiatan pariwisata berbasis pemanfaatan lingkungan untuk perlindungan serta berintikan partisipasi aktif masyarakat dengan penyajian produk bermuatan pendidikan dan pembelajaran, berdampak positif terhadap lingkungan, memberikan kontribusi positif terhadap pembangunan daerah dan diberlakukan pada kawasan lindung, kawasan terbuka, kawasan binaan serta kawasan budaya, maka penelitian ini dilakukan untuk memberikan pengetahuan mengenai ekowisata dalam perspektif hukum lingkungan kepada masyarakat, para perangkat desa serta khususnya pegiat pariwisata di kawasan desa yang ada di Kecamatan Cihurip, Kabupaten Garut, Jawa Barat sebagai salah satu bentuk partisipasi aktif dalam perlindungan dan pengelolaan lingkungan untuk mewujudkan pembangunan berkelanjutan.

Berdasarkan latar belakang di atas, penulis akan membahas lebih lanjut mengenai bagaimana konsep ekowisata diterapkan di Kecamatan Cihurip Kabupaten Garut khususnya dalam rangka perlindungan dan pengelolaan lingkungan hidup.

\section{METODE}

Penelitian ini dilakukan dengan menggunakan metode pendekatan juridis normatif dalam arti menggunakan data kepustakaan/sekunder (baik berupa bahan hukum primer, bahan hukum sekunder maupun bahan hukum tersier) sebagai bahan utama penelitian. Dalam hal ini digunakan metode penelitian yang bersifat deskriptif analitis dengan pendekatan sistemik. 


\begin{tabular}{|c|c|c|c|c|}
\hline $\begin{array}{c}\text { Prosiding Penelitian \& } \\
\begin{array}{c}\text { Pengabdian Kepada } \\
\text { Masyarakat }\end{array}\end{array}$ & $\begin{array}{c}\text { e ISSN : 2581-1126 } \\
\text { p ISSN : 2442-448X }\end{array}$ & Vol 7, No: 1 & Hal: $179-186$ & April 2020 \\
\hline
\end{tabular}

Analisis juridis kualitatif digunakan dengan mengandalkan pada kemampuan abstraksi-teoritis atas bahan-bahan hukum di atas, dengan menggunakan metode penafsiran hukum dan konstruksi hukum, terutama penafsiran sistematis dan penafsiran sosiologis atas peraturan perundang-undangan terkait materi kajian. Pengumpulan data dilakukan dengan studi kepustakaan dan studi lapangan. Data kepustakaan diperoleh dari perpustakaan perguruan tinggi yang diperkirakan memiliki kompetensi di bidang yang terkait. Pengumpulan informasi dilakukan dengan menggunakan metode wawancara dengan narasumber yang ditentukan secara purposif (judgementa). Wawancara dilakukan secara terarah dengan menggunakan pedoman wawancara yang telah disusun sebagai arahannya.

\section{HASI L DAN PEMBAHASAN}

Pariwisata dilakukan oleh beragam penduduk di dunia, sebagai industrl pariwisata adalah multisektor dan sebagai alat pertukaran ekonomi dan budaya, pariwisata memiliki banyak jenis dan bentuk. Artinya, kajian kepariwisataan merupakan suatu kajian multidisiplin. ${ }^{1}$ Perkembangan jenis dan bentuk pariwisata diakibatkan oleh tiga isu utama yaitu pembangunan yang tidak merata dan tidak adil, hubungan kekuasaan dan globalisasi. Dalam hal ini penulis mendapatkan tiga unsur kunci dalam mendefinisikan ekowisata, antara lain ; 1) fokus atraksi pada lingkungan alam atau kawasan spesifik, 2) menekankan pada pembelajaran sebagai bentuk interaksi wisatawan dengan alam, 3) harus berkelanjutan.

Berdasarkan dua kata eco dan tourism, yang ketika diadopsi ke dalam bahasa Indonesia menjadi kata eko dan turisme atau eko dan wisata. Makna dasar dari 2 kata tersebut dapat dijabarkan sebagai berikut, eko yang dalam bahasa Greek (Yunani) berarti rumah, dan tourism yang berarti wisata atau perjalanan. Pengertian selanjutnya

1 Ferdinal Asmin, Ekowisata dan Pembangunan Berkelanjutan: Dimulai dari Konsep Sederhana, Bogor 2018, hlm. 40.

2 Dirawan, G. D. Analisis Sosio-Ekonomi dalam Pengembangan Ekotourisme pada Kawasan Suaka Marga Satwa Mampie Lampoko, Bogor: Institut Pertanian Bogor, 2003, dikutip pada Imam Rudy Kurnianto, "Pengembangan Ekowisata (Ecoourism) di Kawasan Waduk Cacaban Kabupaten Tegal", Tesis, Program Studi Magister IImu Lingkungan Universitas oleh beberapa ahli kata Eco dapat diartikan sebagai Ecology atau Economy sehingga dari kedua kata tersebut akan memunculkan makna Wisata Ekologis (Ecological Tourism) atau Wisata Ekonomi (Economic Tourism) dan hal ini masih terus diperdebatkan oleh para ahli mengenai makna dari kata dasar tersebut. ${ }^{2}$ Menurut Hadi, ${ }^{3}$ prinsipprinsip ekowisata (ecotourism) adalah meminimalisir dampak, menumbuhkan kesadaran lingkungan dan budaya, memberikan pengalaman positif pada turis (visitors) maupun penerima (hosts), memberikan manfaat dan pemberdayaan masyarakat lokal.

Namun, pada hakekatnya, pengertian ekowisata adalah suatu bentuk wisata yang bertanggung jawab terhadap kelestarian alam ( natural area), memberi manfaat secara ekonomi dan mempertahankan keutuhan budaya bagi masyarakat setempat. Pendekatan lain bahwa ekowisata harus dapat menjamin kelestarian lingkungan. Maksud dari menjamin kelestarian ini seperti halnya tujuan konservasi ${ }^{4}$ sebagai berikut: 1. Menjaga tetap berlangsungnya proses ekologis yang tetap mendukung sistem kehidupan. 2 . Melindungi keanekaragaman hayati. 3. Menjamin kelestarian dan pemanfaatan spesies dan ekosistemnya.

Ecotourism adalah sebagian dari sustainable tourism. Sustainable tourism sektor ekonomi yang lebih luas dari ecotourism yang mencakup sektor-sektor pendukung kegiatan tourism secara umum. Menurut deklarasi Quebec (hasil pertemuan dari anggota TIES di Quebec, Canada tahun 2002), Ecotourism adalah sustainable tourism yang secara spesifik memuat upaya-upaya: 1. Konstribusi aktif dalam konservasi alam dan budaya 2. Partisipasi penduduk lokal dalam perencanaan, pembangunan dan operasional kegiatan wisata serta menikmati kesejahteraan. 3. Transfer pengetahuan tentang warisan budaya dan alam kepada pengunjung 4 . Bentuk wisata independen atau kelompok wisata berukuran kecil. ${ }^{5}$

Diponegoro, 2008, hlm. 99, diunduh pada http://eprints.undip.ac.id/17774/1/imam_rudi_kurnnia nto. pdf Selasa, 25 Desember 2018 pukul 19.48 WIB.

3 Hadi S.P., Pariwisata Berkelanjutan (Sustainable Tourism), Makalah Seminar Sosialisasi Sadar Wisata

"Edukasi Sadar Wisata bagi Masyarakat di Semarang", 2007, dikutip pada Imam Rudy Kurnianto, /bid., hlm. 71.

4 United Nations Environment Program (UNEP), dalam Ibid., hlm. 100.

5 /bid., hlm. 101. 


\begin{tabular}{|c|c|c|c|c|}
\hline $\begin{array}{c}\text { Prosiding Penelitian \& } \\
\begin{array}{c}\text { Pengabdian Kepada } \\
\text { Masyarakat }\end{array}\end{array}$ & $\begin{array}{c}\text { e ISSN : 2581-1126 } \\
\text { p ISSN : 2442-448X }\end{array}$ & Vol 7, No: 1 & Hal: $179-186$ & April 2020 \\
\hline
\end{tabular}

Menurut Qomariah (2009), pengertian ekowisata adalah pariwisata yang dipergunakan oleh masyarakat dalam menikmati berbagai jenis keanekaragaman hayati tanpa merusaknya. Wisata ini identik dengan berbagai aktifitas pendidikan, seperti penelitian, dan lain sebagainya. ${ }^{6}$ Menurut Organisasi The Ecotourism Society (1990), ekowisata adalah perjalanan pariwisata seseorang yang dilakukan ke dalam area masih alami dengan tujuan mengkonservasi, melestarikan dan juga mensejahterakan masyarakat yang ada di lingkungan wilayahnya tersebut. ${ }^{7}$

Indonesia melalui pemerintah telah membuat peraturan mengenai ekowisata, dengan dibuatnya Peraturan Menteri Dalam Negeri nomor 33 Tahun 2009 tentang Pedoman Pengembangan Ekowisata di Daerah. Dalam tugas ini penulis akan mengulas mengenai Permendagri tersebut.

Pasal 1 angka (1) Peraturan Menteri Dalam Negeri Nomor 33 Tahun 2009 tentang Pedoman Pengembangan Ekowisata di Daerah, memberi definisi ekowisata sebagai berikut: "Ekowisata adalah kegiatan wisata alam di daerah yang bertanggung jawab dengan memperhatikan unsur pendidikan, pemahaman, dan dukungan terhadap usaha-usaha konservasi sumber daya alam, serta peningkatan pendapatan masyarakat lokal".

Berdasarkan pengertian para ahli dan Permendagri Nomor 33 Tahun 2009, secara garis besar dapat disimpulkan bahwa ekowisata merupakan suatu bentuk wisata alam yang masih alami, yang memberikan manfaat secara ekonomi dan mepertahankan kebudayaan serta masyarakat willayah tersebut.

Latar belakangi lahirnya Peraturan Menteri Dalam Negeri Nomor 33 Tahun 2009 Tentang Pedoman Pengembangan Ekowisata di Daerah ini terdapat dalam preambel-preambel di dalam peraturan tersebut, yaitu ekowisata merupakan potensi sumberdaya alam, lingkungan, serta keunikan alam dan budaya, yang dapat menjadi salah satu sektor unggulan daerah yang belum dikembangkan secara optimal. Pengembangan ekowisata di daerah secara optimal perlu strategi perencanaan, pemanfaatan, pengendalian, penguatan kelembagaan, dan pemberdayaan masyarakat dengan memperhatikan kaidah-kaidah sosial, ekonomi, ekologi, dan melibatkan pemangku kepentingan.

6 Qomariah, Pengembangan Ekowista Berbasis Masyarakat di Taman Nasional Meru Betiri. Institut Pertanian Bogor, 2009.
Pengembangan Ekowisata di Daerah terdiri dari 9 Bab dan berisi 26 Pasal. Pada Bab 1 (Pasal 1) mengatur tentang ketentuan umum. Pada bab ini salah satunya dijelaskan tentang pengertian ekowisata, pengertian pengembangan ekowisata dan lain-lain. J enis dan prinsip ekowisata terdapat dalam Bab 2 (Pasal 2-Pasal3). Pada pasal 1 jenis-jenis ekowisata di daerah antara lain ekowisata bahari, ekowisata hutan, ekowisata pegunungan, dan/atau ekowisata karst. Pengembangan ekowisata dilakukan dengan memperhatikan prinsip-prinsip yang meliputi:

1) Kesesuaian antara jenis dan karakteristik ekowisata;

2) konservasi, yaitu melindungi, mengawetkan, dan memanfaatkan secara lestari sumberdaya alam yang digunakan untuk ekowisata;

3) ekonomis, yaitu memberikan manfaat untuk masyarakat setempat dan menjadi penggerak pembangunan ekonomi di wilayahnya serta memastikan usaha ekowisata dapat berkelanjutan;

4) edukasi, yaitu mengandung unsur pendidikan untuk mengubah persepsi seseorang agar memiliki kepedulian, tanggung jawab, dan komitmen terhadap pelestarian lingkungan dan budaya;

5) memberikan kepuasan dan pengalaman kepada pengunjung;

6) partisipasi masyarakat, yaitu peran serta masyarakat dalam kegiatan perencanaan, pemanfaatan, dan pengendalian ekowisata dengan menghormati nilai-nilai sosial-budaya dan keagamaan masyarakat di sekitar kawasan; dan

7) menampung kearifan lokal. Pada Bab 3 (Pasal 4-Pasal 11) Permendagri mengatur mengenai Perencanaan,

Pemanfaatan dan Pengendalian. Ketiga hal tersebut dilakukan oleh pemerintah daerah. Pada pasal-pasal berikutnya diatur lebih lanjut engenai perancangan, pemanfaatan dan pengendalian ekowisata. Bab 4 (Pasal 12-Pasal 17) mengatur tentang pembentukan tim kordinasi dan secretariat. Pada Pasal 12 dan Pasal 13 disebutkan bahwa yang dapat membentuk tim koordinasi ekowisata adalah Gubernur dan Wali Kota. Dalam

7 Ecotourism: Principles, Practices, and Policies for Sustainability, 1990 


\begin{tabular}{|c|c|c|c|c|}
\hline $\begin{array}{c}\text { Prosiding Penelitian \& } \\
\begin{array}{c}\text { Pengabdian Kepada } \\
\text { Masyarakat }\end{array}\end{array}$ & $\begin{array}{c}\text { e ISSN : 2581-1126 } \\
\text { p ISSN : 2442-448X }\end{array}$ & Vol 7, No: 1 & Hal: $179-186$ & April 2020 \\
\hline
\end{tabular}

menjalankan tugasnya, tim koordinasi dibantu oleh sekretariat tim koordinasi ekowisata. Disebutkan juga dalam Bab 4 pada Pasal 14 susunan kepengurusan tim koordinasi ekowisata terdiri dari: ketua, sekrertaris, dan anggota.

Pada Bab 5 (Pasal 18 dan Pasal 19) pemerintah dan pemerintah daerah dapat memberikan insentif dan kemudahan kepada penanam modal yang melakukan pengembangan ekowisata. Insentif sebagaimana dimaksud antara lain berupa: pengurangan, keringanan atau pembebasan pajak daerah; pengurangan, keringanan atau pembebasan retribusi daerah; pemberian dana stimulan; dan atau pemberian bantuan modal. Pemberian kemudahan sebagaimana dimaksud antara lain berupa: penyediaan data dan informasi peluang penanaman modal; penyediaan sarana dan prasarana; penyediaan lahan atau lokasi; pemberian bantuan teknis, dan/atau percepatan pemberian perizinan.

Bab 6 (Pasal 20-Pasal 21) mengatur tentang Pemberdayaan Masyarakat. Pengembangan ekowisata wajib memberdayakan masyarakat setempat yang dimulai dari perencanaan, pemanfaatan dan pengendalian ekowisata yang diselenggarakan melalui kegiatan peningkatan pendidikan dan keterampilan masyarakat yang harus melibatkan warga masyarakat, lembaga kemasyarakatan, Badan Permusyawaratan Desa, Kader Pemberdayaan Masyarakat, tokoh agama, tokoh masyarakat, dan Lembaga Swadaya Masyarakat.

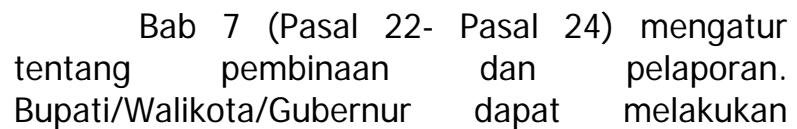
pembinaan terhadap pelaksanaan pengembangan ekowisata di daerahnya masing-masing. Kemudian melaporkan hasil pembinaan secara berurut. Walikota/Bupati depada Gubernur, dan Gubernur kepada Menteri Dalam Negeri. Yang kemudian Menteri dalam negeri juga dapat melakukan pembinaan terhadap pelaksanaan pnegembangan ekowisata di daerah.

Bab 8 (Pasal 25) mengatur tentang Pendanaan. Pendanaan pembinaan pengembangan ekowisata di daerah secara nasional bersumber dari Anggaran Pendapatan dan Belanja Negara dan sumber lainnya yang sah dan

\footnotetext{
8 Penjelasan Pasal 65 Ayat (2) Undang-Undang Nomor 32 Tahun 2009 tentang Perlindungan dan Pengelolaan Lingkungan Hidup.
}

tidak mengikat. Pendanaan pengembangan ekowisata di provinsi bersumber dari Anggaran Pendapatan dan Belanja Daerah Provinsi dan sumber lainnya yang sah dan tidak mengikat. Pendanaan pengembangan ekowisata di kabupaten/kota bersumber dari Anggaran Pendapatan dan Belanja Daerah Kabupaten/Kota dan sumber lainnya yang sah dan tidak mengikat.

\section{Sebagaimana tercantum dalam Undang-} Undang Nomor 32 Tahun 2009 tentang Perlindungan dan Pengelolaan Lingkungan Hidup BAB X Pasal 65 Ayat (1) "Setiap orang berhak atas lingkungan hidup yang baik dan sehat sebagai bagian dari hak asasi manusia" dan Ayat (2) "Setiap orang berhak mendapatkan pendidikan lingkungan hidup, akses informasi, akses partisipasi, dan akses keadilan dalam memenuhi hak atas lingkungan hdup yang baik dan sehat". Hak atas informasi lingkungan hidup merupakan suatu konsekuensi logis dari hak berperan dalam pengelolaan lingkungan hidup yang berlandaskan pada asas keterbukaan. Hak atas informasi lingkungan hidup akan meningkatkan nilai dan efektivitas peran serta dalam pengelolaan lingkungan hidup, di samping akan membuka peluang bagi masyarakat untuk mengaktualisasikan haknya atas lingkungan hidup yang baik dan sehat. Informasi lingkungan hidup sebagaimana dimaksud pada ayat ini dapat berupa data, keterangan, atau informasi lain yang berkenaan dengan perlindungan dan pengelolaan lingkungan hidup yang menurut sifat dan tujuannya memang terbuka untuk diketahui masyarakat, seperti dokumen analisis mengenai dampak lingkungan hidup, laporan, dan evaluasi hasil pemantauan lingkungan hidup, baik pemantauan penaatan maupun pemantauan perubahan kualitas lingkungan hidup dan rencana tata ruang. ${ }^{8}$

Disamping itu juga melekat kewajiban sebagaimana ketentuan Pasal 67 yang menyatakan bahwa "setiap orang berkewajiban memelihara kelestarian fungsi lingkungan hidup serta mengendalikan pencemaran dan/atau kerusakan lingkungan hidup". Dalam rangka perlindungan dan pengelolaan lingkungan hidup, masyarakat memiliki hak dan kesempatan yang sama dan seluas-luasnya untuk ikut berperan aktif dengan melakukan pengawasan sosial, pemberian saran, 


\begin{tabular}{|c|c|c|c|c|}
\hline $\begin{array}{c}\text { Prosiding Penelitian \& } \\
\begin{array}{c}\text { Pengabdian Kepada } \\
\text { Masyarakat }\end{array}\end{array}$ & $\begin{array}{c}\text { e ISSN : 2581-1126 } \\
\text { p ISSN : 2442-448X }\end{array}$ & Vol 7, No: 1 & Hal: $179-186$ & April 2020 \\
\hline
\end{tabular}

pendapat, usul, keberatan, pengaduan, dan/atau penyampaian informasi dan/atau laporan.

Pendidikan lingkungan bertujuan untuk meningkatkan kesadaran, kepedulian tentang lingkungan dengan segala permasalahannya, dan dengan pengetahuan, keterampilan, sikap, motivasi, dan komitmen untuk bekerja secara individu dan kolektif terhadap pemecahan permasalahan dan mempertahankan kelestarian fungsi-fungsi lingkungan. ${ }^{9}$ dengan memperhatikan tujuan tersebut, hal-hal yang perlu dilakukan dalam proses pendidikan lingkungan adalah: ${ }^{10}$

a. Memberikan kesempatan bagi setiap individu untuk memperoleh pengertian dasar tentang lingkungan hidup, permasalahannya serta peran dan tanggung jawab manusia dalam upaya melestarikan fungsi-fungsi lingkungan hidup

b. Membantu individu dan masyarakat mengembangkan keterampilan yang dibutuhkan dalam pengelolaan, menjaga kelestarian fungsi-fungsi lingkungan dan memecahkan permasalahan lingkungan

c. Memupuk kesadaran dan kepekaan terhadap lingkungan hidup dan permasalahannya, melalui penyuluhan terhadap individu atau masyarakat tentang sistem nilai yang sesuai, kepekaan yang kuat atas kepedulian tentang lingkungan dan motivasi untuk secara aktif berpartisipasi terhadap pelestarian fungsifungsi lingkungan dan pencegahan kerusakan lingkungan.

Maka pendidikan lingkungan perlu memenuhi dua kebutuhan masyarakat yang terkait, yaitu: ${ }^{11}$

a. Mengembangkan sumber daya manusia yang berkemampuan teknis yang dilengkapi dengan pengetahuan yang mendalam, keterampilan yang dibutuhkan untuk menilai (asses) dan mengelola lingkungan; dan

b. Menumbuhkan sikap dan perilaku pada masyarakat yang peka dan bertanggung jawab terhadap lingkungan.

Kebutuhan pertama diarahkan pada pemecahan masalah-masalah lingkungan

9 Muhamad Erwin, Hukum Lingkungan - Dalam Sistem Kebijaksanaan Pembangunan Lingkungan Hidup, Bandung: PT Refika Aditama, 2008, hlm. 58-59. sedangkan kebutuhan kedua diarahkan pada peningkatan keampuhan public pressure dalam mempertahankan kelestarian fungsi-fungsi lingkungan dan mencegah kerusakan lingkungan. ${ }^{12}$

\section{Gambar 1. Situ Rancahideung, Kecamatan Cihurip, Kabupaten Garut}

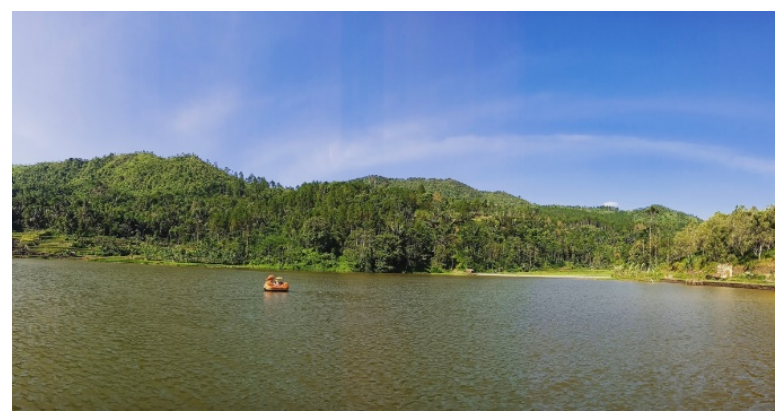

Gambar 2. Leuwi Tonjong, Kecamatan Cihurip, Kabupaten Garut

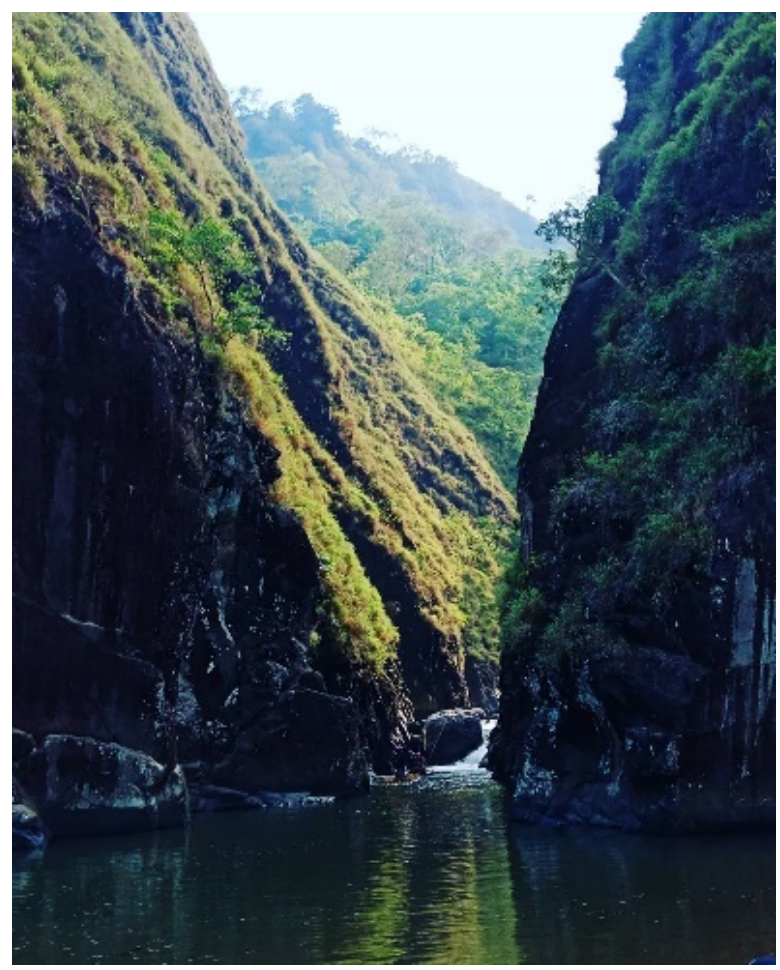

Dalam survei yang dilakukan oleh penulis di Desa Cisangkal, Kecamatan Cihurip, Kabupaten Garut, terdapat 5 tempat wisata atau lebih tepatnya wisata alam alamiah yang sedang dikembangkan oleh pemerintah desa yaitu, Situ

10 Surna T. Djajadiningrat, Jurnal Hukum Lingkungan,Tahun I No. 1/1994, ICEL, J akarta, hlm. 2223, dikutip pada /bid., hlm. 59.

11 /bid.

12 /bid. 


\begin{tabular}{|c|c|c|c|c|}
\hline $\begin{array}{c}\text { Prosiding Penelitian \& } \\
\begin{array}{c}\text { Pengabdian Kepada } \\
\text { Masyarakat }\end{array}\end{array}$ & $\begin{array}{c}\text { e ISSN : 2581-1126 } \\
\text { p ISSN : 2442-448X }\end{array}$ & Vol 7, No: 1 & Hal: $179-186$ & April 2020 \\
\hline
\end{tabular}

Rancahideung, Curug Nyogong, Leuwi Tonjong, serta Curug Cibadak. Situ Rancahideung sendiri merupakan wisata alam yang dikelola sendiri oleh pemerintah daerah Provinsi Jawa Barat Kabupaten Garut dan dibantu oleh penduduk setempat tanpa campur tangan dari pihak luar daerah maupun asing. Keberadaan wisata alam berbeda dengan ekowisata. Ekowisata merupakan salah satu kegiatan pariwisata yang berwawasan lingkungan dengan mengutamakan aspek konservasi alam. Ekowisata dimulai ketika dirasakan adanya dampak negatif pada kegiatan pariwisata konvensional. Dampak negatif ini bukan hanya dikemukakan dan dibuktikan oleh para ahli lingkungan tetapi juga para budayawan, tokoh masyarakat dan pelaku bisnis pariwisata itu sendiri. Dampak berupa kerusakan lingkungan, terpengaruhnya budaya lokal secara tidak terkontrol, berkurangnya peran masyarakat setempat dan persaingan bisnis yang mulai mengancam lingkungan, budaya dan ekonomi masyarakat setempat. Pada mulanya ekowisata dijalankan dengan cara membawa wisatawan ke objek wisata alam yang eksotis dengan cara ramah lingkungan.

\section{Bagan 1. Tanggung jawab Perlindungan dan Pengelolaan Lingkungan}

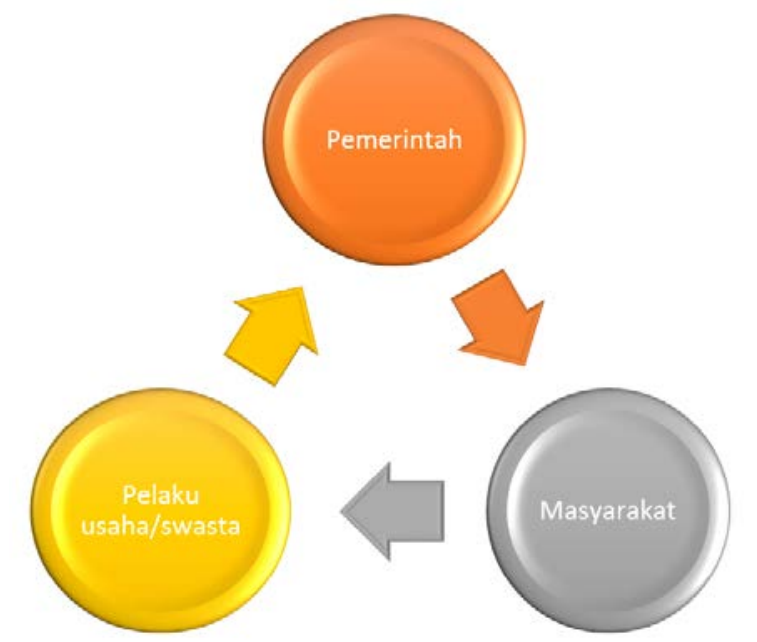

Konsep ekowisata merupakan pengembangan pariwisata yang berkelanjutan untuk mendukung upaya-upaya pelestarian lingkungan (alam dan budaya), meningkatkan partisipasi masyarakat dalam pengelolaan sehingga memberikan manfaat ekonomi bagi

\footnotetext{
13 Peraturan Daerah Kabupaten Garut Nomor 29 Tahun 2011 tentang Rencana Tata Ruang Wilayah Kabupaten Garut Tahun 2011 - 2031
}

masyarakat dan pemerintah lokal. Maka dari itu ekowisata merupakan salah satu cara untuk mewujudkan perlindungan dan pengelolaan lingkungan. Perlindungan dan Pengelolaan Lingkungan bukan hanya merupakan tanggung jawab Pemerintah, Perlindungan dan Pengelolaan Lingkungan hanya dapat berjalan dengan baik jika ada kerjasama dari para pihak.

Penetapan kawasan ekowisata tidak boleh bertentangan dengan arahan pemanfaatan ruang dalam Rencana Tata Ruang dan Wilayah (RTRW) yang terdapat dalam Perda Kabupaten Garut No. 29 Tahun 2011, selain itu harus pula memperhatikan hal-hal seperti: terdapat Pusat Pelayanan Lingkungan (PPL) terdapat pula di desa Cisangkal Kec. Cihurip; Terdapat hutan lindung di Kab. Garut seluas 75.928,37 Ha salah satunya terdapat di Kec. Cihurip; Terdapat hutan rakyat di Kab. Garut seluas $44.010 \mathrm{Ha}$ salah satunya terdapat di Kec. Cihurip; Kawasan Strategis Pariwisata Kabupaten (KSP) Garut Selatan dan sekitarnya dengan sudut kepentingan daya dukung lingkungan hidup salah satunya terletak di Kec. Cihurip. ${ }^{13}$

Sebagaimana prinsip pengembangan ekowisata yang telah disebutkan sebelumnya, diperlu kan adanya partisipasi masyarakat dalam kegiatan perencanaan, pemanfaatan, dan pengendalian ekowisata dengan menghormati nilai-nilai sosial budaya dan keagamaan masyarakat di sekitar kawasan ekowisata. Terkait hal tersebut, tentu juga didukung dengan adanya edukasi bagi masyarakat terkait ekowisata. Pemerintah bertanggung jawab dalam mengembangkan ekowisata dengan memberikan pengetahuan dan pendidikan terkait lingkungan hidup juga bagi pengunjung, dan kaitannya dengan peningkatan perekonomian masyarakat khususnya yang tinggal di sekitar wilayah pengembangan ekowisata. Dengan begitu, hak setiap orang untuk mendapatkan pendidikan lingkungan hidup juga terpenuhi, sebagaimana ketentuan dalam Pasal 65 Ayat (2) UUPPLH. Keberadaan pengunjung yang teredukasi secara otomatis dapat memberikan keuntungan dalam upaya pelestarian lingkungan serta menghasilkan pendapatan dan meningkatkan kesejahteraan masyarakat setempat. Apabila tujuan tersebut dapat dicapai secara optimal, tentu pengunjung 


\begin{tabular}{|c|c|c|c|c|}
\hline $\begin{array}{c}\text { Prosiding Penelitian \& } \\
\begin{array}{c}\text { Pengabdian Kepada } \\
\text { Masyarakat }\end{array}\end{array}$ & $\begin{array}{c}\text { e ISSN : 2581-1126 } \\
\text { p ISSN : 2442-448X }\end{array}$ & Vol 7, No: 1 & Hal: $179-186$ & April 2020 \\
\hline
\end{tabular}

maupun masyarakat akan terus menjaga kelestarian dan keberlangsungan lingkungan.

\section{SI MPULAN}

Ekowisata merupakan salah satu kegiatan pariwisata yang berwawasan lingkungan dengan mengutamakan aspek konservasi alam. Ekowisata dimulai ketika dirasakan adanya dampak negatif pada kegiatan pariwisata konvensional. Dampak negatif ini bukan hanya dikemukakan dan dibuktikan oleh para ahli lingkungan tetapi juga para budayawan, tokoh masyarakat dan pelaku bisnis pariwisata itu sendiri. Dampak berupa kerusakan lingkungan, terpengaruhnya budaya lokal secara tidak terkontrol, berkurangnya peran masyrakat setempat dan persaingan bisnis yang mulai mengancam lingkungan, budaya dan ekonomi masyrakat setempat. Konsep ekowisata termasuk dalam konsep pengelolaan lingkungan hidup, perlindungan dan pengelolaan lingkungan hanya dapat berjalan dengan baik jika ada kerjasama antar para pihak dan masing-masing pihak harus melaksanakan perannya secara optimal.

Pengembangan ekowisata harus memperhatikan kesinambungan antara lingkungan, masyarakat dan pergerakan perekonomian yang terjadi sebelum dan selama ekowisata dijalankan. Selain itu, dalam penyelenggaraan dan pengelolaan kawasan ekowisata, harus memperhatikan unsur pendidikan, perlindungan, keterlibatan masyarakat lokal, pengawasan, dan konservasi. Keterlibatan penduduk lokal harus dimaksimalkan dengan tujuan meningkatkan ekonomi masyarakat setempat.

\section{UCAPAN TERI MAKASI H}

Ucapan terimakasih ditujukan kepada Aparat Pemerintahan di Kecamatan Cihurip Kabupaten Garut, Kelompok pemerhati wisata (Kompepar) di Kecamatan Cihurip, warga desa Kecamatan Cihurip Kabupaten Garut yang telah membantu penulis untuk melakukan penyuluhan dan meneliti tentang ekowisata di Kecamatan Cihurip.

\section{DAFTAR PUSTAKA}

Asmin, F. (2018). Ekowisata dan Pembangunan Berkelanjutan: Dimulai dari Konsep Sederhana. Bogor.

Ecotourism: Principle, Practices, and Policies for Sustainability. (1990).
Enwin, M. (n.d.). Hukum Lingkungan-Dalam Sistem Kebijaksanaan Pembangunan Lingkungan Hidup. Bandung: PT Refika Aditama.

Kurnianto, I. R. (2008). Pengembangan Ekowisata (Ecotourism) di Kawasan Waduk Cacaban Kabupaten Tegal. Universitas Diponegoro. Retrieved from http://eprints.undip.ac.id/17774/1/imam_ru di_kurnnianto.pdf

Peraturan Daerah Kabupaten Garut Nomor 29 Tahun 2011 tentang Rencana Tata Ruang Wilayah Kabupaten Garut Tahun 2011-2031 (2011). Indonesia.

Qomariah. (2009). Pengembangan Ekowisata Berbasis Masyarakat di Taman Nasional Meru Betiri. Bogor.

Undang-Undang Nomor 32 Tahun 2009 tentang Perlindungan dan Pengelolaan Lingkungan Hidup (2009). Indonesia. 